\title{
Intangible fallout from reactor
}

Officials of the International Atomic Energy Agency at Vienna were confident, earlier this week, that they would be able to convene a conference on the damaged Soviet reactor at some stage during the summer. The proposal was raised by the director-general of the agency, Hans Blix, on his visit last week to Moscow. Although a date has not yet been fixed, the Soviet authorities have apparently indicated their willingness to attend, and to bring whatever data are available to them.

The Blix visit was apparently a great success, according to sources close to the agency. Apart from establishing with the Soviet authorities channels of communication for the weeks ahead, the agency officials have been able to check the meaning of statements appearing in routine announcements from Moscow.

Data made public by Blix at press conferences in Moscow are said to be reliable as far as they go, but they refer chiefly to the zone around the plant and not to that within the perimeter fence. But it appears that during the course of a helicopter journey over the damaged plant on 8 May, the personal dosimeters worn by Blix and his companions registered 350 mrem an hour at a height of $400 \mathrm{~m}$ above the plant and at a distance of $800 \mathrm{~m}$. This isolated measurement suggests that the neighbourhood of the plant was still then heavily contaminated.

In the $30-\mathrm{km}$ evacuation zone around the plant, the Vienna agency endorses Soviet statements that dose rates have fallen steadily. The maximum dose rate recorded in the nearby township is said to have been between 10 and 15 mrem an hour soon after the accident, to have fallen to between 2 and 3 mrem an hour on 5 May and now to have declined to 0.15 mrem an hour at the perimeter of the zone.

Conditions at the plant itself are far from clear. Reports that civil engineering works were in hand beneath the reactor suggested to some in the West that those on the spot, having buried the reactor core in 4,000 tonnes of sand and clay, mixed with boron and lead, were concerned that this insulating blanket would allow the presumably molten core to eat its way through the concrete foundations of the reactor. Although the thermal power of freshly irradiated light-water reactor fuel decreases rapidly (by a factor of 50 in 15 minutes) after the shutting down of a reactor, heat production by fission product decay within the fuel remains at close to 0.5 per cent of normal operating power for several days thereafter. This means that the blanked-off reactor core at Chernobyl will have been producing more than 10 MW of thermal power even two weeks after the accident.
In the event, it appears that the threatened catastrophic meltdown has not materialized, although the Soviet authorities say that their objective has been to isolate the reactor from its surroundings as far as possible. (Levees separating the site from the nearby Pripyat river have been raised to prevent run-off from the environs of the plant.)

The first full account of the disaster within the Soviet Union was provided by Pravda on 6 May, in the course of a long article more concerned with the heroism of those who had helped to fight the fires than with factual statements.

Further details were given later on the same day at a press conference attended by Deputy Premier Shcherbina, Dr Andronik Petrosyants (chairman of the state committee on the peaceful uses of atomic energy), Vorob'ev, the deputy minister of health, and the director of the institute of power engineering, Emelyanov.

There is particular satisfaction outside the Soviet Union that the members of the disaster commission include Academician Velikov, the independently-minded vicepresident of the Soviet Academy, who is said by the Soviet press to have been the chief source of technical opinion.

Although the several European states bordering or near the Soviet Union have reported increased levels of activity during the past two weeks, none has suggested that the effects will be permanent or damaging. But in one of the most levelheaded of the statements put out by European governments, the Polish government explained (early last week) that it had placed restrictions on the supply of milk to children because radio-iodine concentrations in milk had exceeded 1,000 becquerels per litre in some parts of northeast Poland, which is the limit suggested by the International Agency for milk fed to children in an emergency.

Complaints that the Soviet Union has been niggardly with information about the disaster have been met both with denials and with the statement that Moscow was inadequately informed by Kiev of the potential scale of the disaster at Chernobyl. The general belief that heads would roll appears to be being fulfilled.

\section{Tokyo summit wants to know more}

Tokyo

LEADERS of the seven leading industrialized democracies arriving in Tokyo for the annual summit last weekend quickly found themselves with an extra topic on the agenda: the Chernobyl nuclear accident. A Japanese call for a response to the incident was backed by the British on Sunday and by Monday a joint statement had been issued.

The statement was essentially a call for the Soviet Union to provide information about the accident and to urge the "early elaboration of an international convention" to commit countries using nuclear power "to report and exchange information in the event of nuclear emergencies or accidents". But the opportunity was not missed to point out the "exacting standards" of "design, manufacture, operation and maintenance" of the nuclear facilities of the seven summit nations (the United States, the United Kingdom, France, West Germany, Italy, Canada and Japan) and of their acceptance of the responsibility to provide "prompt, detailed and complete information on nuclear emergencies and accidents".

The Chernobyl incident also provides a clear message for arms control, according to British Prime Minister Margaret Thatcher, speaking at the end of the summit. She emphasized that "security at a lower level of arms" required verification. If information had been so difficult to obtain from the Soviet Union about a civil reactor, then there would be much greater difficulties in the military field.
The summit statement on Chernobyl coincided with the return of Japanese tourists who had been in the Soviet Union at the time of the accident and the first detection of radioactive fallout in the Japanese skies. For one tourist brought back from Kiev the incident was a tragic reminder: he was a 60 -year-old survivor of the Hiroshima atomic bombing. Radiation 35-140 times the natural average was detected from tourists' luggage and some was placed in custody by the government. Over Japan, radioactive fallout was first detected by high-flying F4 fighter jets on 4 May and by 11 May had been detected in rain in more than half of Japan's prefectures and as far south as Okinawa.

The accident has done little to shake Japan's nuclear industry and a wave of selling of the big electric power utilities' issues on the Tokyo stock market was short-lived. The government showed little reaction to calls by the Japan Socialist Party and the Japan Communist Party to halt the construction of new nuclear plants and to re-examine radically nuclear power policy. Thirty-two nuclear power plants are in operation in Japan, with permission already granted for the construction of another 18 and a further dozen being planned. The accident is bound, however, to strengthen the anti-nuclear movement centred on Fukui prefecture where eleven nuclear plants have been built in one small region. Local citizens have just begun court proceedings to try to stop the construction of the first fast-breeder reactor Monju.

Alun Anderson 